\title{
András László Pap: Democratic Decline in Hungary - Law and Society in an Illiberal Democracy. Routledge, New York, London, 2018.
}

\section{JÁNOS MÉCs*}

The recent profound constitutional and political changes in Hungary provides a topic for both Hungarian and foreign scholars. The illiberal turn in Hungarian constitutional politics gives an example how the classic institutions may be changed in a post-transitional environment and how fragile newly-born democracies are. This scholarly curiosity shows that the topic is relevant not only to the Hungarian academic community but also to scholars of other countries as these changes may eventually take place in their countries. Therefore, the constant monitoring and strengthening of the constitutional institutional order is a task nobody can avoid.

András Pap's book is a contribution to this discourse. The author proclaims right at the beginning of the work that this book is a 'constitutional diary' that describes and evaluates the Hungarian illiberal transition from 2010 to 2012 from a subjective viewpoint. This does not mean, however, that the book does not describe well-established and objectively existent problems but merely that the reader should be aware of the methodological limits and also of the benefits of this format. Regarding the latter, there are many accounts on the morphology and description of the 'Hungarian case' in the literature but it might be highly useful to read the impressions of a Hungarian scholar ${ }^{1}$ as it may reveal scientifically hardly recognizable traits.

The book is divided into two main parts: The first part describes the context, giving a chronological overview of the changes and explains these changes by referring to the societal and constitutional background. The second part delineates the 'microfabric of the Hungarian illiberal democracy' and gives a clear theoretical and terminological background with case studies that show the illiberal nature of the post 2010 Hungarian state.

The first part thus contains two main chapters: A chronology and explanation chapter. The first gives a detailed description of the 'U-turn' that took place in the first two years of Viktor Orbán's Fidesz-KDNP government, starting from 2010. The aim of this chapter is not only to give an outline of the events, but also to 'show the substance of illiberalism: institutionalizing the tyranny of the majority; a 'clientelist' decision-making regime that defies rule of law principles; dismantling core institutional guarantees for government control; passing laws that curtail individual liberties [...] and adopting an ideologically biased constitution that cements the above-described developments and initiatives.' ${ }^{2}$

* PhD student, Eötvös Loránd University, Faculty of Law, research assistant, Hungarian Academy of Sciences, Centre for Social Sciences, Institute for Legal Studies. E-mail: mecs.janos@tk.mta.hu.

${ }^{1}$ András László Pap is Head of Department at the Hungarian Academy of Sciences Centre for Social Sciences, Institute for Legal Studies and holds another positions related to the academic sphere and universities.

2 See: Pap (2018) 12. 
The book thus describes the different events and techniques leading towards an illiberal constitutional architecture, pointing out the main steps of the transition, starting from the dubious legislative practices through the restriction of constitutional court powers to the adoption of the new constitution - the Fundamental Law.

The second chapter analyses the possible causes and explanations. The changes in Hungary cannot be understood without the broader societal circumstances, and indeed, the author gives an overview of the values and political culture of the Hungarian society. He shows figures pointing out that democracy and the classic constitutional values such as rule of law are and were not wide-spread and well supported in the society. This disappointment and despair gave way to a rhetoric based on the promise of change that inevitably involved the denial of these classic values. Besides economic hardships, the constitutional background is also mentioned with the author referring to the 'political cold war' that was instrumentalized in Fidesz, and to the constructive vote of non-confidence that made stable and not-removable governments.

The second part starts with the theoretical background of illiberalism, identifying it as the constituent part of Hungary's new constitutional identity. The author uses the term illiberal referring to 'a constitutional and political condition that creates a middle ground between a constitutional democracy and an autocracy. ${ }^{3}$ In order to identify the illiberal characteristics of the 'System of National Cooperation' ('SNC'), the author analyses the Fundamental Law and other important declarations and speeches, arguing that illiberalism had been important feature of the transition since the beginning and that the new regime redefined the relationship between the state and the citizens, creating new institutional and normative terms, and that it departed from the classic values of liberal constitutionalism and concept of personhood. The chapter argues convincingly, however, as the author himself recognizes by citing the scholar and former ECtHR judge András Sajó 'it is a mistake to put ideas and improvisations of East European politicians up for serious and unreflected scientific scrutiny and comparative analysis. ${ }^{4}$ Indeed, in the case of the Orbán regime, it is hard to establish a solid and coherent underlying ideology, maybe because such ideology would restrict the political power of its leader by creating normative standards other than the 'sheer law of politics.' Nevertheless the author does not fall into this trap, as he introduces the section as a thought-experiment 'based on the presumption that there is a substantive theoretical construction' behind, and his theoretical findings do not have substantial explanatory function in the book, they rather give one piece of the mosaic.

The theoretical part is followed by case studies showing examples of the illiberal nature of the new government. The fourth chapter shows how, with a 'new social contract', the SNC is built on the traditional (or conservative) principles of work, Christianity, family and on the conservative understanding on gender, sexual orientation and reproductive rights, and on a paternalistic attitude towards the citizens. The author argues with exact figures that these values do not represent the value-set of the society; there is a clear gap between the value-set of the Fundamental Law and of the society. It is also argued that these 'paternalistic, patriarchal, heteronormative' value preferences may be discriminative regarding the minorities and should be left to the ethical debates in society to be decided.

\footnotetext{
3 See: Pap (2018) 49.

${ }^{4}$ See: Pap (2018) 48.
} 
The fifth and the sixth chapters also present case studies but go further in time, seeking answer to the question that to what extent were they products of path dependence, i.e., whether they were predetermined by the pre-2010 era. The fifth chapter shows the phenomenon labelled 'illiberal multiculturalism' and argues that by amending the citizenship law and making possible diaspora members to gain citizenship and by granting the right to vote to these people, the government touched upon an internationally delicate issue and 'committed' gerrymandering. The author argues that this process was greatly path dependent as the issue was on the political agenda before 2010. The chapter also shows the relationship between the nation and the minorities, arguing that there were no clear political objectives and that this led to flawed conceptualisation and terminology. Special emphasis is put on the Roma minority, arguing that they were affected the worst by both the previous and subsequent events.

The final sixth chapter 'investigates how the Fundamental Law and subsequent recent legislation conceptualizes and operationalizes personhood and constitutionally recognized groups. ${ }^{, 5}$ Pap argues that the new political community is not based on individual freedom but on collective rights and duties. The dignity of communities are protected, even the dignity of the majority, which results in the paradox situation, e.g., in hate speech and hate crimes can be committed against members of the majority, however these institutions are widely regarded as defenders of minorities. Another example is the case of classically liberal instruments that are used in order to defend the illiberal state. In these cases, privacy is extended to obstruct the transparency of state agencies. The author gives a detailed description of cases e.g., the Prosecutor General initiating legal processes against newspapers questioning the effectiveness or legality of his office. A third example is the privacy as a tool for ethnic discrimination and marginalization. Pap shows how the strict rules on data protection regarding ethnic origin are used to obscure discriminative practices e.g., on behalf of the police.

Besides acknowledging its merits, a few critical points could be raised regarding the book. The first is the question of the role of the constitutional background in the illiberal transition. While the book gives important cornerstones to understand the proceedings from a democracy to an illiberal state and it was admittedly not written in order to give a structured explanation, in my view, certain factors are also needed to be mentioned. Although the author gives short remark on the role of the constitutional background, he does not go into detail regarding this matter. It would have been important to note shortly the role of the electoral system, the party system, the lack of real-coalition and the lack of intra-party opposition. The constructive vote of non-confidence is mentioned; however the stability of the Fidesz-KDNP government is supported and was enabled by deeper structural characteristics. A monolith party was built in which practically no intra-party opposition exists, the coalition is a formality where no bargaining is involved; the party system and thus the political landscape is extremely divided, where there is effectively no chance that the opposition can form a single alliance. Finally and maybe most importantly, the electoral system was and is disproportionate, allowing PM Orbán to win two-third majority with 52.7, 43.5, and 49.3 percent of the popular vote (results from 2010, 2014 and 2018 respectively). ${ }^{6}$ It would have been useful to mention the disproportionality of the electoral system because it gives an explanation to the paradox situation that is described greatly by

\footnotetext{
5 See: Pap (2018) 126.

6 For the results see $<$ http://www.valasztas.hu/> accessed 21 September 2018.
} 
the book, the cleavage between the values and in-life practices of society and of the Fundamental law. $^{7}$

Another critical point may be raised with regard to certain statements that could have been more established either by further explanation or by citation. One example is the question of gerrymandering. As mentioned above, the author argues that the extension of the right to vote of non-resident Hungarians could be seen as gerrymandering. While this is true that the governmental parties are (and were) dramatically overrepresented among the diaspora and thus, in effect, these changes were beneficial for them, the allegations of gerrymandering in my view are too strong to be established by this mere fact. Further conceptualization would be needed to determine the standards for this type of 'gerrymandering.'

These, however, are far from being fundamental flaws and do not annul the merits of the book, which are beyond dispute. The book is well structured and offers a thoughtprovoking insight into the Hungarian illiberal transition. It approaches the problem both from the abstract-terminological perspective and from case-studies. Thus, it avoids the trap of neglecting any of these circumstances and factors. It gives a detailed background, taking into consideration the historical and societal circumstances that are inevitable to understand the current situation of Hungary. The account could be useful both for Hungarian and foreign scholars and it could be a starting point of further research.

7 In Hungary the voter turnout is usually around 60-70 percent, which means that if a constitutional power may be gained with 52.7 percent of the votes, as it happened in 2010 , then there may be just one-third of the voters' vote behind the constitutional power, and roughly one fifth of the whole population. 